\title{
Investigating the Role of Financial Knowledge, Financial Skills and Behavioral Control in Explaining Individuals' Successfulness in Managing Personal Finances
}

\author{
Dajana Barbić
}

\begin{abstract}
Determining what affects financial successfulness of consumers and identifying the strength and the nature of the relationship between financial knowledge, financial skills and financial behaviour is very important as many individuals are indebted and have experienced serious financial problems. The relevant research indicates that many individuals no matter the level of their financial knowledge and financial skills still make serious financial mistakes and fail to manage their finances successfully. Behavioural economists analysed errors that occur in financial behaviour of individuals and confirmed the significance of psychological factors. The objective of this research is to investigate the transformation of what consumers know about personal finances into how they actually manage them, where behavioural control is also examined as a potential moderator of that relationship. In order to analyze the relationship between the variables, multiple regression and moderation analysis are used. Findings suggest that individuals' financial success depends on all of the examined variables. Furthermore, the moderation effect of behavioural control was partially confirmed.
\end{abstract}

Keywords---Financial Successfulness, Financial Knowledge, Financial Skills, Behavioural Control, Personal Finances, Financial Mistakes, Moderation Analysis, Multiple Regression Analysis.

\section{INTRODUCTION}

According to the findings of many studies financial knowledge and financial skills are very important in the context of determining one's financial wellbeing (Cvrlje, 2014). Hilgert et al (2003) found the evidence of positive relationship between financial knowledge and individuals' involvement in good financial practices such as regular bill payment, monitoring expenses, creating and maintaining a budget, creating an emergency fund, diversifying investments and increased household solvency. They concluded that financial knowledge and financial skills might be very important predictors of successful decision making. Lusardi (2008) showed that financial knowledge and skills affect financial decision-making and concluded that ignorance about basic financial concepts and financial calculations can be linked to poor financial behavior of individuals and low Dajana Barbić i Faculty of Economics and Business, University of
Zagreb financial successfulness. In her opinion, those who are more financially knowledgeable and have developed good financial skills should be much more likely to engage in personal finance planning (Lusardi, 2008). Collins (2010) suggested that financial knowledge has a positive effect on successful financial behavior of individuals. Many other authors in their studies came to the same conclusion (Boyce and Danes, 1998; Bernheim and Garrett, 2003; Lusardi 2004; Lusardi and Mitchell, 2008; Stango and Zinman, 2009; Gale and Levine, 2011) and confirmed the existence of positive relationship between financial knowledge and various forms of successful financial behavior. Furthermore, some studies reported positive correlation between numerical skills and financial well-being of the individuals (Banks et al., 2010) where numerical skills and general cognitive abilities proved to be good predictors of various forms of financial successfulness (Banks and Oldfield, 2007; Gerardi et al., 2010).

However, there are some studies which emphasize that the link between financial knowledge, financial skills and successful financial decision making, is not a simple as it might seem at first. Although the evidence of numerous studies may lead to the conclusion that financial literacy should result in improved financial decision making and increased wellbeing of households, some studies suggest otherwise. Hastings et al. (2013a) have found inconsistencies in the financial behavior of many individuals, even those with high level of financial knowledge and skills. Moreover, in everyday life we may find many examples where financially educated individuals make poor financial decisions and face serious financial problems (Cvrlje, 2014). The answer to such inconsistencies may be found in the fact that some relationships might be affected and changed by a third variable. Examples of such variables include moderators, mediators, suppressors and covariates (MacKinnon et al., 2000). Moreover, in the social sciences it is often a challenge to find those relationships in which some effect can be explained only by a single variable (Vashdi, 2013). For this reason, more and more studies include the effects of third variables on the basic relations. There are some factors, which are generally very little investigated, such as psychological variables which according to the behavioral economists could affect the relationship between financial knowledge, financial 
skills and the way in which individuals make their financial decisions (Pompian, 2006). Throughout the literature investigating human attitudes and behavior, one of the most commonly investigated psychological factors includes locus of control which is very similar to behavioral control. Behavioral control is one of the psychological factors that might make people take financial risks and make financial decisions with possibly disastrous consequences for their financial wellbeing (Gärling et al, 2010). Since persons' own view of the control over financial decision making is very important, behavioral control is included in the analysis and moderation effect of behavioral control is also examined in this paper.

Finally, it can be concluded that in terms of the effectiveness of financial knowledge and financial skills, there is still no consensus in the relevant literature. Furthermore, it is evident that there is room for more detailed investigations of this issue by using credible empirical methodology by which it is possible to determine whether, and under what conditions, the increase of financial knowledge and skills will lead to more successful financial decision-making and better financial behavior. Furthermore, it will be clear whether behavioral control is important in this process and in what extent. The results of this study will be very useful for individuals and households but also for economic and education policy makers.

\section{II.LITERATURE REVIEW AND HYPOTHESIS DEVELOPMENT}

\section{A. Financial knowledge}

Financial knowledge includes theoretical and practical understanding of financial concepts and objects. There are many ways that a person may acquire financial knowledge, including formal, non-formal and informal financial education (Pastuović, 2008). According to Atkinson and Messy (2012) individuals with higher level of financial knowledge should be able to make rational decisions which are very important to create an efficient financial market. The general assumption is that the increase of financial knowledge will result in the improvement of the behavior. Many studies confirmed the relationship between knowledge and behavior (Hogarth et al., 2003). The lack of knowledge on financial principles, money management and other financial matters is one of the possible explanations why some individuals manage their resources inefficiently and do not follow the recommended financial practices. According to the survey conducted by Hilgert and Hogarth (2003) individuals who scored better on the financial knowledge test showed to be more inclined to use the recommended financial practices such as regular bill payments, creating a savings fund in case of uncertainty etc. Furthermore, in another study Hilgert et al (2003) found that individuals who are financially knowledgeable are more likely to behave in financially responsible ways. According to the presented findings it is predicted that individuals with higher level of financial knowledge will display more successful financial behavior. This prediction is reflected in Hypothesis 1. H1: There is a positive relationship between financial knowledge and successfulness in managing personal finances.

\section{B. Financial Skills}

Financial skills present specific numerical, statistical and logical abilities that relate to the capability to compute, convert and understand financial calculations such as computing percentages, understanding interest rates and inflation, calculating interest and such. It is essential to distinguish between the general and basic numerical skills (Lipkus et al., 2001; Peters et al., 2006). The general assumption is that numerically literate person can manage and respond to the mathematical demands of life. Some authors have researched the connection between specific financial skills and some financial outcomes such as debt, savings and investments, in order to examine the relevance and applicability of financial skills in the matters of personal finance management. The results of the analysis indicate to positive correlation between financial skills and financial outcomes (Lusardi and Mitchell, 2008, ANZ Bank, 2008). Study conducted by Banks et al. (2010) suggests that individual's lack of mathematical and numerical skills can have a significant negative impact on his welfare. Moreover, they imply that individuals with higher levels of numerical skills often enjoy financial well-being, as compared with individuals with a lower level of numerical skills. Research conducted by Gerardi et al. (2010) confirmed the correlation between low level of numerical skills, on the one hand, and problems with repayment of mortgage loans, on the other hand. According to the findings presented in the relevant literature, individuals with higher level of financial skills should display more successful financial behavior. Therefore, this study suggests a following hypothesis. H2: There is a positive relationship between financial skills and successfulness in managing personal finances.

\section{Behavioral Control}

Studies have shown that the way people perceive themselves and the world around them has an influence on their financial and non-financial preferences and largely determines their behavior (Onkivisist and Shaw, 1987; Hira and Mugenda, 1999; Cvrlje, 2014). In his work, Rubenstein (1981) concludes that the feelings and opinions that people have about money primarily depend on their opinion and feelings about their own life. Furthermore, in his research Tokunaga (1993) confirms the existence of a positive correlation between locus of control and accumulated debt on credit cards. As currently viewed by Ajzen (2002), perceived behavioral control is an overarching construct that includes self-efficacy as well as controllability. According to the findings presented, in this paper it is hypothesized that lower level of behavioral control should be negatively associated with successfulness in managing personal finances. Therefore, following hypothesis is proposed. H3: There is a positive relationship between high level of behavioral control and successfulness in managing personal finances

Psychology literature and behavioral economics suggest 
that the relationship between what individuals know and how they behave may be moderated by some correlated variables (Eagly and Chaiken, 1993). Therefore, it is important to investigate whether individual's behavioral control affects the transformation of financial knowledge into financial successfulness i.e. financial skills into financial successfulness. These predictions are reflected in Hypothesis 4 and Hypothesis 5. H4: Behavioral control moderates the relationship between financial knowledge and successfulness in managing personal finances; H5: Behavioral control moderates the relationship between financial skills and successfulness in managing personal finances.

\section{Research Model}

Based on the above presented findings of the relevant literature, the following research model is proposed.

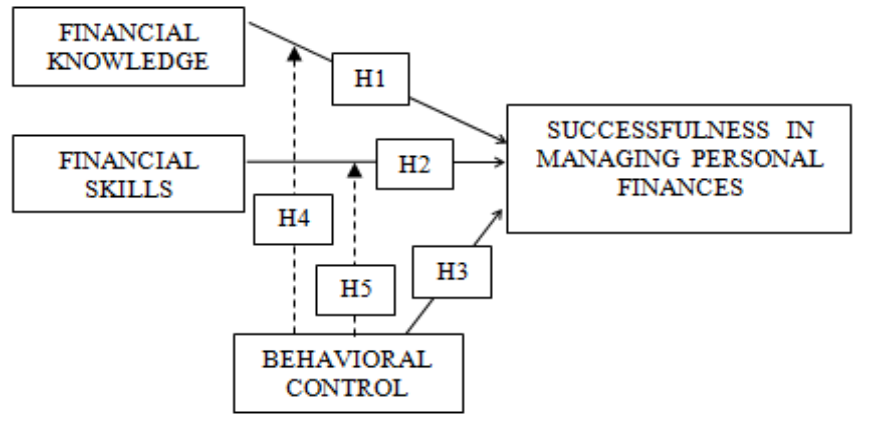

\section{MethodOLOGY}

\section{A. Research design}

The research was conducted in two phases: pilot study and the main study. The pilot study was undertaken with a purpose of refining the scales used in the questionnaire. The final questionnaire was administered in the form of telephone survey using the base of randomly selected telephone numbers. The measurements of all constructs are based on previous studies. Specifically, the financial knowledge and financial skills scales are based on the research done by Lusardi and Mitchell (2011) for the American HRS in 2004. Individuals' behavioral control was assessed using three items developed by Nysveen et al (2005). Using three, five-point Likert-type statements, the scale measures one's subjective degree of control over performance of a particular behavior, in this case, financial behavior. Nysveen et al. (2005) used the scale with mobile services but it appears to be amenable for use with other types of behavior as well. The construct reliability for the scale was 0.77 (Nysveen et al., 2005). Successfulness in managing personal finances scale was adapted from Cvrlje (2014). Using five, five-point Likert-type statements, the scale measures one's performance in making successful financial decisions and behaving responsibly. The construct reliability for the scale was 0.85 .

Fig. 1: Research model

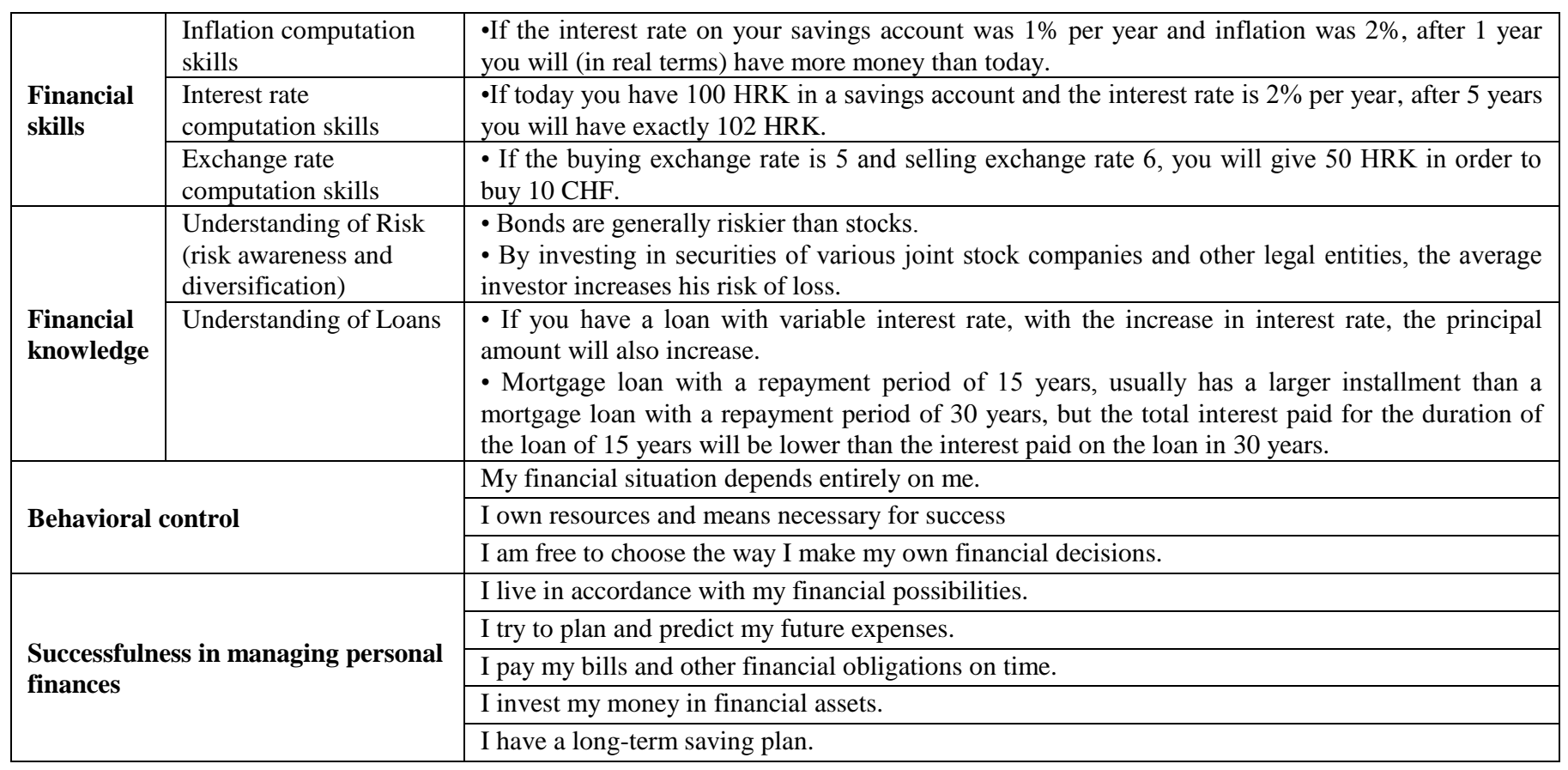

\section{B. Sampling and research method}

The pilot testing was conducted on a judgmental sample of 30 respondents, aged 20-79 years, living in Zagreb, using snowball sampling. Feedback from the pilot test was used in finalizing the structured questionnaire. The final study population comprised 387 randomly chosen active (employed and unemployed) respondents living in Croatia, aged 20-79 years.

The assumptions tested in the hypothesis $\mathrm{H} 1, \mathrm{H} 2$ and $\mathrm{H} 3$ is that people who have higher levels of financial knowledge, financial skills and behavioral control will be more successful in managing their own finances than those who have lower levels of financial knowledge, financial skills and behavioral control. Testing was conducted using multiple linear 
regression analysis in the software package EViews8. After the regression analysis was conducted, in order to test hypothesis $\mathrm{H} 4$ and $\mathrm{H} 5$, the second step included moderation analysis.

\section{THE RESULTS OF THE MODEL ESTIMATION}

\section{A. Figures and Tab Respondents' characteristics}

Total of 387 respondents from 20 to 79 years old were included in this research. Initial analysis of data showed that $57,37 \%$ of respondents were women and $42,63 \%$ were men. The major percentage of respondents were from 25 to 59 years old $(85 \%)$, followed by 60 to 79 years old (10\%) and $5 \%$ of respondents 20 to 24 years.

\section{B. Results on hypothesis testing}

\section{Regression analysis $(\mathrm{H} 1, \mathrm{H} 2, \mathrm{H} 3)$}

The regression assumptions of linearity, homoscedasticity, and normality (Cohen, 1998) were first examined. The results indicated that there was no violation of the basic assumptions of linearity or residual homoscedasticity. Detecting abnormalities was carried out using Jarque-Bera test. The results showed that there was no statistically significant departure from normality, which met the residual normality assumption in the regression analysis $(\mathrm{p}=0.633486)$.

In the next phase correlations among the variables were examined. Results of the covariance analysis showed that successfulness in managing personal finances (SIPF) is positively related to financial knowledge (FK), financial skills

TABLE I

REGRESSION ANALYSIS (EVIEWS8)

\begin{tabular}{|c|c|c|c|c|}
\hline \multicolumn{5}{|c|}{ Dependent Variable: SIPF } \\
\hline \multicolumn{5}{|c|}{ Method: Least Squares } \\
\hline Variable & Coefficient & Std. Error & t-Statistic & Prob. \\
\hline $\mathrm{C}$ & 8.015280 & 0.637976 & 12.56361 & 0.0000 \\
\hline FK & 0.316147 & 0.141971 & 2.226840 & 0.0265 \\
\hline FS & 0.349036 & 0.185554 & 1.881044 & 0.0607 \\
\hline $\mathrm{BC}$ & 0.693021 & 0.057401 & 12.07324 & 0.0000 \\
\hline R-squared & 0.329175 & \multicolumn{2}{|c|}{ Mean dependent var } & 16.45220 \\
\hline Adjusted R-squared & 0.323920 & \multicolumn{2}{|c|}{ S.D. dependent var } & 3.940577 \\
\hline S.E. of regression & 3.240103 & \multicolumn{2}{|c|}{ Akaike info criterion } & 5.199369 \\
\hline Sum squared resid & 4020.836 & \multicolumn{2}{|c|}{ Schwarz criterion } & 5.240283 \\
\hline Log likelihood & -1002.078 & \multicolumn{2}{|c|}{ Hannan-Quinn criter. } & 5.215593 \\
\hline F-statistic & 62.64619 & \multicolumn{2}{|c|}{ Durbin-Watson stat } & 2.025465 \\
\hline Prob(F-statistic) & 0.000000 & & & \\
\hline
\end{tabular}

accounted for an additional 26, $8 \%$ of the variance in

\section{A. Moderation analysis (H4)}

In the hierarchical regression, in Step 1, financial knowledge was entered as predictor variable. In Step 2, besides financial knowledge, behavioral control was entered as a second predictor variable. In Step 3, besides financial knowledge and behavioral control, their interaction term was entered $(\mathrm{FKxBC})$ to examine the interaction/moderation effects. Step 1, results indicate that financial knowledge accounts for $5,5 \%$ of the variance in successfulness in managing personal finances. In Step 2, behavioral control
(FS) and behavioral control (BC). According to Evans (1996) the correlation between SIPF and FK and FS is weak $(0,234$; 0,246) while the correlation between SIPF and BC is moderate $(0,543)$. Furthermore, the relationship between FK and FS is positive and the strength of their correlation is moderate $(0,571)$. Relationship between $\mathrm{BC}$ and both FK and FS is positive, however the strength of their correlation is very weak $(0,128 ; 0,165)$. After examining correlations, next step included multiple regression analysis using the Least square method. The results of the regression analysis are shown in Table 1. According to the results, the following regression equation is formulated, whereby the standard errors are shown in the brackets:

$$
\mathrm{y}=0,316147 \mathrm{X} 1+0,349036 \mathrm{X} 2+0,696021 \mathrm{X} 3
$$$$
\begin{array}{lll}
(0.141971) \quad(0.185554) \quad(0.057401)
\end{array}
$$

where $\mathrm{y}$ represents successfulness in managing personal finances, X1 financial knowledge, X2 financial skills and X3 behavioral control. According to the evaluated model, when FK increases for 1 unit, SIPF will increase for 0,316147 units. Moreover, when FS increase for 1 unit, SIPF will increase for 0.349036 units. Finally, when BC increases for 1 unit, SIPF will increase for 0.693021 units. This evaluation confirmed the existence of positive relation between variables in the model and assumptions tested in hypothesis $\mathrm{H} 1, \mathrm{H} 2$ and $\mathrm{H} 3$. 
TABLE II

RESULTS OF THE MODERATION ANALYSIS 1

\begin{tabular}{|c|c|c|c|c|c|c|c|}
\hline Steps & Predictor & Beta & $\mathbf{t}$ & $\mathbf{p}$ & $\mathbf{R 2}$ & Adj. R2 & $\begin{array}{l}\text { Moderation } \\
\text { effect }\end{array}$ \\
\hline Step 1 & Financial knowledge & 0.652946 & 4.739867 & 0.0000 & 0.055137 & 0.052682 & \multirow{6}{*}{ No } \\
\hline \multirow{2}{*}{ Step 2} & Financial knowledge & 0.466454 & 3.961867 & 0.0001 & \multirow{2}{*}{0.322977} & \multirow{2}{*}{0.319451} & \\
\hline & Behavioral control & 0.705258 & 12.32544 & 0.0000 & & & \\
\hline \multirow{3}{*}{ Step 3} & Financial knowledge & 0.692407 & 1.620842 & 0.1059 & \multirow{3}{*}{0.323512} & \multirow{3}{*}{0.318213} & \\
\hline & Behavioral control & 0.742391 & 8.387821 & 0.0000 & & & \\
\hline & $\begin{array}{l}\text { Financial knowledge } \mathrm{X} \\
\text { Behavioral control }\end{array}$ & 0.021891 & 0.550280 & 0.5824 & & & \\
\hline
\end{tabular}

\section{Moderation analysis (H5)}

As in the previous model the moderation effect was examined through three steps. In Step 1, results indicate that financial skills account for $6,07 \%$ of the variance in successfulness in managing personal finances. In Step 2, behavioral control accounted for an additional $25,97 \%$ of the variance in successfulness in managing personal finances. In Step 3, interaction of financial skills and behavioral control turn to be statistically significant and the total variance explained increased by an extra 2,79\%. If after the inclusion of the moderator variable, there are indices of a statistically

TABLE III

RESULTS OF THE MODERATION ANALYSIS 2

\begin{tabular}{|c|c|c|c|c|c|c|c|}
\hline Steps & Predictor & Beta & $\mathbf{T}$ & $\mathbf{p}$ & $\mathbf{R 2}$ & Adj. R2 & $\begin{array}{l}\text { Moderation } \\
\text { effect }\end{array}$ \\
\hline Step 1 & Financial skills & 0.891041 & 4.991670 & 0.0000 & 0.060785 & 0.058345 & \multirow{6}{*}{ Yes } \\
\hline \multirow{2}{*}{ Step 2} & Financial skills & 0.581599 & 3.772655 & 0.0002 & \multirow{2}{*}{0.320489} & \multirow{2}{*}{0.316950} & \\
\hline & Behavioral control & 0.698358 & 12.11455 & 0.0000 & & & \\
\hline \multirow{3}{*}{ Step 3} & Financial skills & 2.652501 & 4.973570 & 0.0000 & \multirow{3}{*}{0.348383} & \multirow{3}{*}{0.318213} & \\
\hline & Behavioral control & 1.032960 & 10.31734 & 0.0000 & & & \\
\hline & $\begin{array}{ll}\text { Financial skills } & X \\
\text { Behavioral control } & \end{array}$ & 0.203779 & 4.049090 & 0.0001 & & & \\
\hline
\end{tabular}

purpose of this study was to examine the moderation effect of

\section{Conclusion}

The first purpose of this study was to examine whether financial knowledge, financial skills and behavioral control were significantly related to successfulness in managing personal finances. The findings supported this hypothesis. The results of this study point to a significant positive association between the variables and they not only support but also extend the existing literature. This study demonstrated that among the three variables examined in this study, behavioral control is the one that contributes to the financial successfulness of individuals the most, followed by financial skills, and at the end financial knowledge which was found to be a variable with the least contribution. This implies that one's subjective degree of control over performance of a financial behavior should be managed with special attention. This should be very valuable for the designers of financial education programs since they should pay additional attention to the development of individuals' sense of control and work on building the right financial attitude towards financial planning and personal finance management. The second significant contribution in the proportion of explained variance criteria $\left(\mathrm{R}^{2}\right)$, it can be concluded that moderation effect is present. The results of the conducted analysis suggest that behavioral control moderates the relationship between financial skills and successfulness in managing personal finances $A n R^{2}$ value of 0,348 indicates a small moderation effect size (Cohen, 1998). However, interaction terms usually account for about 1 to $3 \%$ of the variance in social science studies (Chaplin, 1991) so this result may be interpreted as expected. The assumption made in hypothesis H5 was confirmed. behavioral control on the relationship between financial knowledge and successfulness in managing personal finances i.e. financial skills and successfulness in managing personal finances. The moderation analysis showed that behavioral control does not moderate the relationship between financial knowledge and financial successfulness. However, behavioral control was found to be a significant moderator of the relationship between financial skills and financial successfulness. This results suggest that the higher level of behavioral control heightened the strength of the association between financial skills and successfulness in managing personal finances. Conversely, lower level of behavioral control weakened this association.

\section{ACKNOWLEDGMENT}

This work has been fully supported by Croatian Science Foundation under the project STRENGTHS no 940. 


\section{REFERENCES}

[1] Ajzen, I. „Perceived behavioral control, self-efficacy, locus of control, and the theory of planned behavior". Journal of Applied Social Psychology, 665-683, 2002. https://doi.org/10.1111/j.1559-1816.2002.tb00236.x

[2] ANZ Bank,"ANZ Survey of Adult financial literacy in Australia", Roy Morgan Research, 2008

[3] Atkinson, A. and F. A. Messy, "Measuring financial literacy: Results of the OECD/ International Network on Financial Education, Working Papers on Finance, Insurance and Private pensions, 2012

[4] Banks, J. and Z. Oldfield, "Understanding Pensions: Cognitive Functions, Numerical ability and Retirement Saving", Fiscal Studies, pp. 143-170, 2007 https://doi.org/10.1111/j.1475-5890.2007.00052.x

[5] Banks, J., O’Dea, C. and Z. Oldfield, "Cognitive function, numeracy and retirement saving trajectories", Economic Journal, pp. 381-410, 2010 https://doi.org/10.1111/j.1468-0297.2010.02395.x

[6] Bernheim, B. D. and D. M. Garrett, "The effects of financial education in the workplace: Evidence from survey of households", Journal of Public Economics, 1487-1519, 2003 https://doi.org/10.1016/S0047-2727(01)00184-0

[7] Boyce L. B. and S. M. Danes, "Evaluation of the NEFE high school financial planning program", National Endowment for Financial Education, 1998

[8] Chaplin, W. F., "Moderator and mediator Research in Personality Psychology", Journal of Personality, 1991 https://doi.org/10.1111/j.1467-6494.1991.tb00772.x

[9] Cohen, J. S., Statistical power analysis for the behavioural sciences, Eribaum: NJ Hillsdale, 1998

[10] Collins, J. M., "The impacts of manadatory financial education: evidence from a randomized field study", Working Paper, Center for financial security, 2010

[11] Cvrlje, D., "Povezanost koncepta financijske pismenosti s uspješnošću u upravljanju osobnim financijsma", Doctoral thesis , 2014

[12] Eagly, A. and S. Chaiken, The psychology of attitudes, Harcourt Brace Jovanovich College Publishers, 1993

[13] Gale, W. and R. Levine, "Financial literacy: What works? How could it be effective?", Center for retirement, 2011

[14] Gerardi, K., Goette, L., S. Meier, "Financial literacy and subprime mortgage deliqency: evidence from a survey matched to administrative data", Working Paper, 2010

[15] Hastings, J. C., Madrian, B. C., W. L. Skimmyhorn, "Financial literacy, financial education and economic outcomes", Annual review of economics, pp. 347-373, 2013a https://doi.org/10.1146/annurev-economics-082312-125807

[16] Hilgert, M. A., Hohart, J.M. and S.G. Beverly, "Household Financial Management: The connection between knowledge and behavior", Federal Reserve Bulletin, pp. 309-322, 2003

[17] Hira, K. T. and O. Mugenda, "Do men and women differ in their financial beliefs and behaviors?", Proceedings of the Eastern Family Economics Resource Management Association, 1999

[18] Hung, A.A., Parker, A.M. and J.K. Yoong, "Defining and measuring financial literacy,", Working Paper, 2009

[19] Lipkus, I. M., Samsa, G. and B.K. Rimer, B. K., "General performance on a Numeracy Scale among highly educated samples", Medical Decision Making, Vol.1, pp. 37-44, 2001 https://doi.org/10.1177/0272989X0102100105

[20] Lusardi, A., "Savings and effectiveness of financial education", Working Paper, 2004

[21] Lusardi, A. and O.S. Mitchell, "Financial literacy and planning : Implications for Retirement Wellbeing", NBER Working Paper, 2011

[22] Lusardi, A." Financial Literacy: Essential Tool for Informed Consumer Choice?", Bulletin on Aging and Health, 2008

[23] MacKinnon, D. P., Krull, J. L., and C. M. Lockwood, "Equivalence of the mediation, confounding, and suppression effect", Prevention Science, Vol.1, pp.173-181, 2000 https://doi.org/10.1023/A:1026595011371

[24] Nysveen, H., Pedersen, P. E. and H. Thorbjørnsen, "Intentions to use mobile services: Antecedents and cross-service comparisons", Journal of the Academy of Marketing Science, Vol.3, pp. 330-346, 2005 https://doi.org/10.1177/0092070305276149
[25] Onkvisit, S. and J. Shaw, "Self-Concept And Image Congruence: Some Research And Managerial Implications", Journal of Consumer Marketing, Vol.4, pp. 38-50, 1987 https://doi.org/10.1108/eb008185

[26] Pastuović, N., "Cjeloživotno učenje i promjene u obrazovanju", Odgojne znanosti, Vol. 10, pp. 253-267, 2008

[27] Pompian, M. M., Behavioral Finance and Wealth Management, John Wiley \& Sons, Inc., Hoboken, New Jersey, 2006

[28] Stango, V. and J. Zinman, "Exponential Growth Bias and Household Finance", Journal of Finance, pp. 2807- 2849, 2009 https://doi.org/10.1111/j.1540-6261.2009.01518.x

[29] Tokunaga, H., "The use and abuse of consumer credit: Application of psychological theory and research", Journal of Economic Psychology, Vol. 14, pp. 285-316, 1993 https://doi.org/10.1016/0167-4870(93)90004-5 